CARPATHIAN JOURNAL OF FOOD SCIENCE AND TECHNOLOGY

journal homepage: http://chimie-biologie.ubm.ro/carpathian_journal/index.html

\title{
EFFECTS OF PROCESSING ON ESSENTIAL AND HEAVY METAL COMPOSITION OF POPULAR FISH SPECIES CONSUMED IN THE KARACHI COAST OF THE ARABIAN SEA
}

\author{
Fatima Hayat Shaheen Zafar ${ }^{1}$, Mohammad Zahid ${ }^{1}$, Levent Bat ${ }^{2}$ \\ ${ }^{1}$ Department of Zoology, Federal Urdu University of Arts, Science and Technology, 75270 Karachi, Pakistan \\ ${ }^{2}$ Department of Hydrobiology, Fisheries Faculty, Sinop University, TR57000 Sinop, Turkey \\ *fatimahamood@yahoo.com
}

https://doi.org/10.34302/crpjfst/2019.11.2.11

\begin{tabular}{ll}
\hline Article history: & ABSTRACT \\
Received: & This study analyzed three popular species of fish in raw and cooked (curried \\
24 November 2018 & and fried) form, commonly consumed in Karachi coast and overall in \\
Accepted: & Pakistan for their essential and heavy metal composition. The outcomes \\
\multicolumn{1}{c}{ 15 May 2019 } & revealed that the content of toxic heavy metal (Hg) was observed in all raw \\
\hline Keywords: & samples particularly in raw Mulla fish (Lethrinus nebulosus) but heat \\
Acanthopagrus arabicus; & treatment by frying and curry preparation of fish led to a decrease of Hg \\
Lethrinus nebulosus; & content in the muscles of all selected species especially in L. nebulosus after \\
Pampus argentus; & frying. While in Acanthopagarus arabicus Hg content was below detectable \\
Arabian Gulf; & level. In this study the levels of Cd and Cr were observed at below detectable \\
Heavy metal. & levels in all selected species except in A. arabicus where Cd tend to decrease \\
& after frying while the content of Cr slightly increase after both types of \\
& cooking. In the present study the essential metals namely Fe, Zn, Cu and Mn \\
& tend to increase in all fin fishes after cooking, especially in curried form. \\
& The above-mentioned result determined that these customary culinary \\
practices of fish have an influence on their essential and heavy metal \\
constituents. Furthermore, eating variety of fin fish species by applying \\
different procedures of cooking is the finest attempt to attain better-quality \\
of dietetic ways, minimizing mercury revelation and increasing chance to \\
obtain vital elements.
\end{tabular}

\section{Introduction}

Toxic heavy metal pollution, which is obstinate and bio accumulative, progressively intimidates marine environment (Balkas et al., 1982; Bat et al., 2009; Bat, 2014). The metal pollutants in marine coastal system normally persist either in soluble or suspended form and finally tend to sink to the bottom or are taken up by the biota (Bat and Raffaelli 1998; Bat 2005; Khattak and Khattak, 2013; Bat and Özkan, 2015; Bat et al., 2015; Bat et al., 2017). Unfortunately, some heavy metals and their compounds are considered cancerous for humans and animals (Stanescu, 1998). Certain metals for instance $\mathrm{Cd}, \mathrm{Pb}$, and $\mathrm{Hg}$ are extremely lethal even at very slight amounts (Bat, 2014; Bat, 2017). For example, $\mathrm{Cd}$ and $\mathrm{Hg}$ are familiar to cause kidney diseases, high blood pressure, cancer, hepatic dysfunction and harm reproductive ability while $\mathrm{Pb}$ can cause renal malfunction, liver mutilation, reduced hearing or produce mental obstruction, whereas at high intensities in women can result in a reduced conception period (Iwegbue, 2011). Hg, lethal effects have been emphasized when combined poisoning reported after consuming large amount of fish by people (Renzoni et al., 1998; Chen et al., 2002). $\mathrm{Cu}, \mathrm{Fe}, \mathrm{Mn}$, and $\mathrm{Zn}$ are 
crucial and compulsory for regular body activity like the synthesis of metalloproteinase. Although lack of these metals might lead to illness, unnecessary consumptions of these metals could initiate prolonged inflammatory sickness and a possible factor of tumor (Naughton and Petroczi 2008). Heavy metals can be hazardous to consumer's health (Diaconescu et al., 2012; Bat, 2014; Bat, 2017; Bat and Arici, 2018). Usually heavy metals store in fleshy tissue of fish and so, the intensities determined in their tissues are able to reveal the former exposure (Ashraf, 2005).

Karachi, Pakistan is a coastal metropolitan and thus facing industrialization difficulty. Hence, adjacent coastal regions of the Arabian Sea are getting an immense amount of unregulated industrial manure discharges that eventually disturb aquatic life (Jaffer et al., 1995; Tariq et al., 1998). Earlier studies have evidenced enhanced levels of these metals in fish belonging to south west coast of Pakistan (Tariq et al., 1998).

Usually fish species are consumed in cooked form while most of research studies information made from uncooked/raw products (Domingo, 2011). For the meantime heavy metal evaluation in raw products does not present the accurate calculations of these metals intake via seafood ingestion and consequently, it is essential to establish the accumulations of heavy metals in raw and cooked fish (Kalogeropoulos, 2012). Some study proven that the heavy metals concentrations of fish can also be changed by processing and hence, it is likely to decrease the toxic heavy metal concentration in fillets by selecting a proper technique of cooking (Kalay et al., 1999; Ersoy et al., 2006; Diaconescu et al., 2013). Many investigations have recorded a remarkable decline of the heavy metals in fish after cooking, while specific works mentioned rise in the metal amount. The works that revealed a reduction of toxic metals usage cooking processes subjected to cooking terms, such as time, temperature, and cooking medium (Morshey et al., 2015). Metal concentrations in fish are highly dependent on fish size (Ahmed et al., 2016). According to Burger and Gochfeld (2011), the people must be well-informed prior to decide on which kind of fish is suitable to intake, how often and in what portion.

Though research studies are present on the heavy metal composition of raw fish, but studies to evaluate the essential and heavy metals composition of cooked fish in the Arabian Sea areas are rare. Furthermore, in Pakistan, almost none of the data exist on the impacts of traditionally processing on the essential and heavy metal concentrations in fish fillet. This study is consequently, an effort to evaluate the concentration of vital and toxic heavy metals in selected raw and traditionally proceed fish species usually consumed in Karachi.

\section{Materials and methods}

\subsection{Materials}

\subsubsection{Collection of samples}

Only the popular edible fish species of Karachi were included in this study. All fish were purchased from the local fish markets in Karachi city of Pakistan. Local, common, scientific names are presented in (Table 1). The selected culinary methods for selected fish species are common to most of the Pakistan and even in sub-continent.

Table 1. Common, Local and Scientific names of fish species included in the study

\begin{tabular}{|l|l|l|}
\hline \multicolumn{1}{|c|}{$\begin{array}{c}\text { Common } \\
\text { name }\end{array}$} & \multicolumn{1}{|c|}{$\begin{array}{c}\text { Local } \\
\text { name }\end{array}$} & \multicolumn{1}{|c|}{ Scientific name } \\
\hline White Pomfret & $\begin{array}{l}\text { Safeed } \\
\text { Poplet }\end{array}$ & Pampus argentus \\
\hline $\begin{array}{l}\text { Arabian yellow-finned } \\
\text { sea bream }\end{array}$ & Dhandya & $\begin{array}{l}\text { Acanthopagrus } \\
\text { arabicus }\end{array}$ \\
\hline Spangled Emperor & Mulla & Lethrinus nebulosus \\
\hline
\end{tabular}

The fish were all captured from the coast of Karachi. On board they were put covered with ice and were later on shipped in a refrigerated truck to the central market. The selected fish species were purchased randomly during the period of August 2016 to February 2018. About $5 \mathrm{~kg}$ of each species of whole fish were captured, kept in icebox and immediately transferred to the PCSIR Laboratory of Karachi without delay, 
where the identification and measurement of samples were taken.

For cooking purpose, vegetables like onion, tomato, garlic and mix spices, for coating of fish fillet, gram flour and sunflower cooking oil were purchased from local super market.

\subsubsection{Sample preparation and cooking}

Fish samples were washed with distilled water several times. The samples were cleaned as per usual cooking practices (scaling, beheading, gutting and removing the internal organs). Fillets were made for Yellow fin Bream, Mulla and Pomfret fishes. They were washed with water then fish fillet were divided into three groups, the first one is uncooked and the other two groups were cooked. Two different cooking methods were applied on fish species which are traditionally used on domestic and commercial level in local people. The frying of the marinated fish species was performed in a domestic nonstick pan (2-Litre capacity) at medium flame approximately for 15 minutes and fish curry was cooked with chopped vegetables and spices for 30 to 35 minutes in low to medium flame (Table 2).

Sunflower oil was used for frying and cooking in curry form. After cooking, samples cooled and kept below $4^{\circ} \mathrm{C}$ till analyzed in laboratory for essential and heavy metal concentration.

\subsection{Methods}

\subsubsection{Heavy Metal Analysis}

All chemicals used were of Analytical Regent (AR) Grade either of Merck or equivalent. Three fillet samples of each type raw or cooked fish selected at random and were dried in oven at $80^{\circ} \mathrm{C}$ for 3-4 hrs. The completely dried sample was homogenized with the help of pestle and mortar. For testing of $\mathrm{Fe}, \mathrm{Zn}, \mathrm{Cu}, \mathrm{Mn}, \mathrm{Pb}, \mathrm{Cr}$ and $\mathrm{Cd}, 4-5 \mathrm{gm}$. of each sample in triplicate was weighed in a beaker and was soaked overnight in 5ml Conc. Nitric Acid. 10-15 ml deionized distilled water was added to the samples and the contents were heated at $60-80^{\circ} \mathrm{C}$ on a hotplate till samples were completely digested. Contents were filtered through Whatman 41in $25 \mathrm{ml}$ volumetric flask and the volume was made with deionized distilled water. Sample blank was also prepared in the same manner, $5 \mathrm{ml}$ Nitric acid was mixed with $10-15 \mathrm{ml}$ deionized distilled water and heated on a hotplate for the same duration as for the samples. Samples were analyzed on Hitachi Z- 5000 Polarized Zeeman Flame/Graphite Furnace Atomic Absorption Spectrophotometer against standard curve. The instrument was handled as per manufacturer direction. Dilutions were made if needed to keep sample concentration between linear ranges of working curve.

For the analysis of $\mathrm{Hg}, 4-5 \mathrm{~g}$ of each sample in triplicate was reflux in $30 \mathrm{ml}$ acid digestions mixture containing 1:1 nitric and sulfuric acid till contents are completely digested and all nitric acid is removed. Samples were diluted and solution was made up to $250 \mathrm{ml}$ in volumetric flask with de-ionized distilled water. Sample blank was also made using similar method. Mercury was analyzed using same Hitachi Z 5000 Polarized Zeeman Flame/Graphite Furnace Atomic Absorption Spectrophotometer through cold vapor unit installed with the equipment against working curve. The instrument was handled as per manufacturer instructions. Dilutions were made if needed to keep sample concentration between linear ranges of working curve.

Metal contents were expressed as ppb for $\mathrm{Hg}$, and $\mathrm{ppm}$ for $\mathrm{Cu}, \mathrm{Fe}, \mathrm{Mn}, \mathrm{Cd}, \mathrm{Cr}, \mathrm{Pb}$ and $\mathrm{Zn}$ wet wt. of fresh fish.

\subsubsection{Statistical analysis}

The effect of different cooking methods on the proximate and heavy metal composition of selected fish was analyzed using standard deviation (SD).

The yearly quantity of fish consumed is $2 \mathrm{~kg}$ per person in 2006 (Food and Agriculture Organization of the United Nations 2009), which is same as $5.48 \mathrm{~g} /$ day for Pakistan. The EDI of metals was determined using the following equation (Bat and Arici, 2018).

$$
\mathrm{EDI}=\mathrm{C}_{\text {metal }} \times \mathrm{W} / \text { b.w. }
$$


Where: $\mathrm{C}_{\text {metal }}$ is the concentration of metals in fish; $\mathrm{W}$ represents the per diem mean intake of fish; b.w. is the body weight.

Table 2. Ingredients and traditional methods of preparation of fish species commonly consumed in Karachi, Pakistan

\begin{tabular}{|l|c|c|c|c|c|c|}
\hline Species & $\begin{array}{c}\text { Cooking } \\
\text { process }\end{array}$ & $\begin{array}{c}\text { Sample } \\
\text { size }(\mathrm{g})\end{array}$ & $\begin{array}{c}\text { Oil used } \\
(\mathrm{ml})\end{array}$ & Ingredients & $\begin{array}{c}\text { Method of } \\
\text { preparation }\end{array}$ & $\begin{array}{c}\text { Cooking time } \\
(\mathrm{min})\end{array}$ \\
\hline \multirow{2}{*}{ Pampus argentus } & Fried & 100 & 200 & $*$ & $* * *$ & $10-15$ \\
\cline { 2 - 7 } & Curry & 100 & 60 & $* *$ & $* * * *$ & $25-30$ \\
\hline \multirow{2}{*}{ Lethrinus nebulosus } & Fried & 100 & 200 & $*$ & $* * *$ & $10-15$ \\
\cline { 2 - 7 } & Curry & 100 & 60 & $* *$ & $* * * *$ & $25-30$ \\
\hline \multirow{2}{*}{ Acanthopagrus arabicus } & Fried & 100 & 200 & $*$ & $* * *$ & $10-15$ \\
\cline { 2 - 7 } & Curry & 100 & 60 & $* *$ & $* * * *$ & $25-30$ \\
\hline
\end{tabular}

* Spices containing mainly, salt, red chili powder, turmeric powder, fresh garlic paste and gram flour for coating.

** Spices containing yellow mustard seed, onion, tomatoes, yoghurt, salt, red chili powder, turmeric powder and fresh garlic paste.

*** Wash the fillet/shrimp with salt and vinegar mix water then clean tap water, fillets coated with spices mix gram flour batter leave for 15 minutes in refrigerator for batter grip of coated ingredients then fry in moderate hot sunflower oil till brown.

**** Wash the fillet with salt and vinegar mix water then clean tap water, roast/brown the grind vegetables, yoghurt and spices in hot sun flower oil then add fillet in gravy and cooked in low to moderate heat till done.

\section{Results and discussion}

\subsection{Heavy Metals Content}

The recovery of the spiked metals was close to $97-99 \%$ for all tested metals by proposed method.The mean concentrations $( \pm \mathrm{SD})$ of heavy metals in raw, fried and curried form of fish muscles are given in Tables 3-5.

In $P$. argentus $\mathrm{Fe}, \mathrm{Zn}$ and $\mathrm{Cu}$ contents were increased conspicuously in fried forms as compared to their raw forms. While as compare to raw samples the amounts of $\mathrm{Mn}$ and $\mathrm{Hg}$ were decreased in fried fish. Mn value was slightly higher in curried form whereas Fe value was low. The $\mathrm{Hg}$ content was decreased in fried form as compare to its curried and raw. The $\mathrm{Cd}, \mathrm{Cr}$ and $\mathrm{Pb}$ contents were below the detectable level in raw and cooked forms of white Pomfret fish (Table 3).

In L. nebulosus the amount of $\mathrm{Fe}$ was remarkably increased in curried form than fried form as compare to its raw form. The amount of $\mathrm{Hg}$ is very higher observed in raw form while after frying it was surprisingly decreased more than seven fold. The other heavy metal contents showed slightly increased after cooking. On the other hand $\mathrm{Cd}, \mathrm{Cr}$ and $\mathrm{Pb}$ contents were below the detectable levels in raw and cooked forms (Table 4).

In A. arabicus $\mathrm{Fe}, \mathrm{Zn}, \mathrm{Cu}$ and $\mathrm{Mn}$ levels slightly increase in fried form while $\mathrm{Cd}$ amount decrease after frying and increase after cooked in curried form. The amount of $\mathrm{Cr}$ was slightly increased after both types of cooking as compare to raw form. The amounts of $\mathrm{Hg}$ and $\mathrm{Pb}$ were below the detectable levels in all raw and cooked samples of Bream fish (Table 5).

According to people well-being risk, the allowable weekly intakes were calculated by means of references for eatable tissues of fishes consumed by people. The EWI (Estimated Weekly Intake) and EDI (Estimated Daily Intake) levels showed in Tables 6-8, were estimated by assuming that a $70-\mathrm{kg}$ person will consume $5.48 \mathrm{~g}$ fish per day which is even 38.36 $\mathrm{g}$ fish per week (see statistical analysis in Materials and Methods). 
Table 3. Mean \pm SD of heavy metal concentrations given $\mathrm{mg} / \mathrm{kg}$ except $\mathrm{Hg}(\mu \mathrm{g} / \mathrm{kg})$ wet wt. in Raw and cooked Pampus argentus (white Pomfret fish)

\begin{tabular}{|l|c|c|c|c|c|c|c|c|}
\hline Form & $\mathrm{Fe}$ & $\mathrm{Zn}$ & $\mathrm{Cu}$ & $\mathrm{Mn}$ & $\mathrm{Hg}$ & $\mathrm{Cd}$ & $\mathrm{Cr}$ & $\mathrm{Pb}$ \\
\hline Raw & $86 \pm 1.1$ & $36 \pm 0.42$ & $2.2 \pm 0.21$ & $14 \pm 0.96$ & $11 \pm 0.29$ & $\mathrm{Nd}^{*}$ & $\mathrm{Nd}^{*}$ & $\mathrm{Nd}^{*}$ \\
\hline Fried & $108 \pm 2.12$ & $95 \pm 1.04$ & $18 \pm 0.21$ & $9.5 \pm 0.78$ & $5.9 \pm 0.15$ & $\mathrm{Nd}^{*}$ & $\mathrm{Nd}^{*}$ & $\mathrm{Nd}^{*}$ \\
\hline Curried & $72 \pm 1.14$ & $49 \pm 0.49$ & $3.7 \pm 0.22$ & $17 \pm 0.29$ & $7.9 \pm 0.26$ & $\mathrm{Nd}^{*}$ & $\mathrm{Nd}^{*}$ & $\mathrm{Nd}^{*}$ \\
\hline
\end{tabular}

$\mathrm{Nd}^{*}=$ non detectable (below the detectable level)

Table 4. Mean \pm SD of heavy metal concentrations given $\mathrm{mg} / \mathrm{kg}$ except $\mathrm{Hg}(\mu \mathrm{g} / \mathrm{kg})$ wet wt. in Raw and cooked Lethrinus nebulosus (Mulla fish).

\begin{tabular}{|l|c|c|c|c|c|c|c|c|}
\hline Form & $\mathrm{Fe}$ & $\mathrm{Zn}$ & $\mathrm{Cu}$ & $\mathrm{Mn}$ & $\mathrm{Hg}$ & $\mathrm{Cd}$ & $\mathrm{Cr}$ & $\mathrm{Pb}$ \\
\hline Raw & $34 \pm 0.5$ & $16 \pm 0.21$ & $1.4 \pm 0.17$ & $0.7 \pm 0.15$ & $144 \pm 1.21$ & $\mathrm{Nd}^{*}$ & $\mathrm{Nd}^{*}$ & $\mathrm{Nd}^{*}$ \\
\hline Fried & $53 \pm 0.62$ & $13 \pm 0.25$ & $2.1 \pm 0.21$ & $2.1 \pm 0.25$ & $20 \pm 0.26$ & $\mathrm{Nd}^{*}$ & $\mathrm{Nd}^{*}$ & $\mathrm{Nd}^{*}$ \\
\hline Curried & $74 \pm 1.36$ & $19 \pm 0.26$ & $1.7 \pm 0.23$ & $3.9 \pm 0.29$ & $47 \pm 0.98$ & $\mathrm{Nd}^{*}$ & $\mathrm{Nd}^{*}$ & $\mathrm{Nd}^{*}$ \\
\hline
\end{tabular}

$\mathrm{Nd}^{*}=$ non detectable (below the detectable level)

Table 5. Mean \pm SD of heavy metal concentrations given $\mathrm{mg} / \mathrm{kg}$ except $\mathrm{Hg}(\mu \mathrm{g} / \mathrm{kg})$ wet wt. in Raw and cooked Acanthopagrus arabicus (Arabian yellow fin bream fish).

\begin{tabular}{|l|c|c|c|c|c|c|c|c|}
\hline Form & $\mathrm{Fe}$ & $\mathrm{Zn}$ & $\mathrm{Cu}$ & $\mathrm{Mn}$ & $\mathrm{Hg}$ & $\mathrm{Cd}$ & $\mathrm{Cr}$ & $\mathrm{Pb}$ \\
\hline Raw & $16.3 \pm 0.15$ & $3.79 \pm 0.006$ & $1.53 \pm 0.03$ & $0.29 \pm 0.04$ & $\mathrm{Nd}^{*}$ & $0.008 \pm 0.002$ & $0.138 \pm 0.002$ & $\mathrm{Nd}^{*}$ \\
\hline Fried & $16.71 \pm 0.02$ & $4.41 \pm 0.006$ & $2.68 \pm 0.05$ & $0.59 \pm 0.02$ & $\mathrm{Nd}^{*}$ & $0.006 \pm 0.003$ & $0.188 \pm 0.011$ & $\mathrm{Nd}^{*}$ \\
\hline Curried & $19.98 \pm 0.24$ & $1.03 \pm 0.06$ & $1.32 \pm 0.03$ & $0.7 \pm 0.01$ & $\mathrm{Nd}^{*}$ & $0.023 \pm 0.003$ & $0.156 \pm 0.001$ & $\mathrm{Nd}^{*}$ \\
\hline
\end{tabular}

$\mathrm{Nd}^{*}=$ non detectable (below the detectable level)

Table 6. Estimated Weekly Intakes (EWI) and Estimated Daily Intakes (EDI) of heavy metals in edible tissues of Pampus argentus (white Pomfret fish) from the local fish markets in

Karachi city of Pakistan.

\begin{tabular}{|l|l|l|l|l|l|l|l|l|l|}
\hline \multirow{2}{*}{ Metals } & \multirow{2}{*}{ PTWI $^{\mathrm{a}}$} & \multirow{2}{*}{ PTWI $^{\mathrm{b}}$} & \multirow{2}{*}{ PTDI $^{\mathrm{c}}$} & \multicolumn{3}{|c|}{ EWI $^{\mathrm{d}}$} & \multicolumn{3}{c|}{ EDI $^{\mathrm{e}}$} \\
\cline { 5 - 10 } & & & & Raw & Fried & Curried & Raw & Fried & Curried \\
\hline $\mathrm{Fe}$ & 5.6 & 392 & 56 & 3.29896 & 4.14288 & 2.76192 & 0.47128 & 0.59184 & 0.39456 \\
\hline $\mathrm{Zn}$ & 7 & 490 & 70 & 1.38096 & 3.6442 & 1.87964 & 0.19728 & 0.5206 & 0.26852 \\
\hline $\mathrm{Cu}$ & 3.5 & 245 & 35 & 0.084392 & 0.69048 & 0.141932 & 0.012056 & 0.09864 & 0.020276 \\
\hline $\mathrm{Mn}$ & $2-5$ & $140-350$ & $20-50$ & 0.53704 & 0.36442 & 0.65212 & 0.07672 & 0.05206 & 0.09316 \\
\hline $\mathrm{Hg}$ & 0.005 & 0.35 & 0.05 & 0.0004 & 0.00023 & 0.0003 & 0.00006 & 0.00003 & 0.00004 \\
\hline $\mathrm{Cd}$ & 0.007 & 0.49 & 0.07 & \multicolumn{3}{|c|}{ Not detectable (below the detactable level) } \\
\hline $\mathrm{Cr}$ & 0.0233 & 1.631 & 0.233 & \multicolumn{3}{|c|}{ Not detectable (below the detactable level) } \\
\hline $\mathrm{Pb}$ & 0.025 & 1.75 & 0.25 & \multicolumn{3}{c|}{ Not detable (below the detactable level) } \\
\hline
\end{tabular}

aPTWI (Provisional Tolerable Weekly Intake) in $\mathrm{mg} / \mathrm{week} / \mathrm{kg}$ body wt.

bPTWI for $70 \mathrm{~kg}$ adult person (mg/week/70 kg body wt.)

'PTDI (Permissible Tolerable Daily Intake) (mg/day/70 kg body wt.)

${ }^{d}$ EWI (Estimated Weekly Intake) (mg/week/ kg body wt.)

${ }^{\mathrm{e}} \mathrm{EDI}$ (Estimated Daily Intake) (mg/day/ kg body wt.) 
Table 7. Estimated Weekly Intakes (EWI) and Estimated Daily Intakes (EDI) of heavy metals in edible tissues of Lethrinus nebulosus (Mulla fish) from the local fish markets in

Karachi city of Pakistan.

\begin{tabular}{|l|l|l|l|l|c|c|c|c|c|}
\hline \multirow{2}{*}{ Metals } & \multirow{2}{*}{ PTWI $^{\mathrm{a}}$} & \multirow{2}{*}{ PTWI $^{\mathrm{b}}$} & \multirow{2}{*}{ PTDI $^{\mathrm{c}}$} & \multicolumn{3}{|c|}{ EWI $^{\mathrm{d}}$} & \multicolumn{3}{c|}{ EDI $^{\mathrm{e}}$} \\
\cline { 5 - 10 } $\mathrm{Fe}$ & 5.6 & 392 & 56 & 1.30424 & 2.03308 & 2.83864 & 0.18632 & 0.29044 & 0.40552 \\
\hline $\mathrm{Zn}$ & 7 & 490 & 70 & 0.61376 & 0.49868 & 0.72884 & 0.08768 & 0.07124 & 0.10412 \\
\hline $\mathrm{Cu}$ & 3.5 & 245 & 35 & 0.053704 & 0.08056 & 0.065212 & 0.00767 & 0.01151 & 0.009316 \\
\hline $\mathrm{Mn}$ & $2-5$ & $140-350$ & $20-50$ & 0.026852 & 0.08056 & 0.149604 & 0.00384 & 0.01151 & 0.021372 \\
\hline $\mathrm{Hg}$ & 0.005 & 0.35 & 0.05 & 0.0055 & 0.00076 & 0.00182 & 0.00078 & 0.00011 & 0.00026 \\
\hline $\mathrm{Cd}$ & 0.007 & 0.49 & 0.07 & \multicolumn{6}{|c|}{ Not detectable (below the detactable level) } \\
\hline $\mathrm{Cr}$ & 0.0233 & 1.631 & 0.233 & \multicolumn{3}{|c|}{ Not detectable (below the detactable level) } \\
\hline $\mathrm{Pb}$ & 0.025 & 1.75 & 0.25 & \multicolumn{3}{c|}{ Not detectable (below the detactable level) } \\
\hline
\end{tabular}

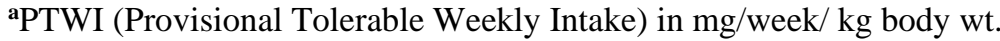

${ }^{b}$ PTWI for $70 \mathrm{~kg}$ adult person (mg/week/70 kg body wt.)

'PTDI (Permissible Tolerable Daily Intake) (mg/day/70 kg body wt.)

dEWI (Estimated Weekly Intake) (mg/week/ kg body wt.)

${ }^{e}$ EDI (Estimated Daily Intake) (mg/day/ kg body wt.)

Table 8. Estimated Weekly Intakes (EWI) and Estimated Daily Intakes (EDI) of heavy metals in edible tissues of Acanthopagrus arabicus (Arabian yellow fin bream fish) from the local fish markets in Karachi city of Pakistan.

\begin{tabular}{|c|c|c|c|c|c|c|c|c|c|}
\hline \multirow{2}{*}{ Metals } & \multirow{2}{*}{$\mathrm{PTWI}^{\mathrm{a}}$} & \multirow{2}{*}{ PTWI $^{\mathrm{b}}$} & \multirow{2}{*}{$\mathrm{PTDI}^{\mathrm{c}}$} & \multicolumn{3}{|c|}{$E I^{d}$} & \multicolumn{3}{|c|}{$\mathrm{EDI}^{\mathrm{e}}$} \\
\hline & & & & Raw & Fried & Curried & Raw & Fried & Curried \\
\hline $\mathrm{Fe}$ & 5.6 & 392 & 56 & 0.625268 & 0.6409 & 0.76643 & 0.08932 & 0.0916 & 0.10949 \\
\hline $\mathrm{Zn}$ & 7 & 490 & 70 & 0.14538 & 0.1692 & 0.03951 & 0.02077 & 0.0242 & 0.0056 \\
\hline $\mathrm{Cu}$ & 3.5 & 245 & 35 & 0.05881 & 0.1028 & 0.0506 & 0.0084 & 0.0147 & 0.0072 \\
\hline $\mathrm{Mn}$ & $2-5$ & $140-350$ & $20-50$ & 0.0111 & 0.0226 & 0.0269 & 0.0016 & 0.0032 & 0.0038 \\
\hline $\mathrm{Hg}$ & 0.005 & 0.35 & 0.05 & \multicolumn{6}{|c|}{ Not detectable (below the detactable level) } \\
\hline $\mathrm{Cd}$ & 0.007 & 0.49 & 0.07 & 0.0003 & 0.0002 & 0.0009 & 0.00004 & 0.00003 & 0.0001 \\
\hline $\mathrm{Cr}$ & 0.0233 & 1.631 & 0.233 & 0.0053 & 0.0072 & 0.0059 & 0.0008 & 0.0010 & 0.0009 \\
\hline $\mathrm{Pb}$ & 0.025 & 1.75 & 0.25 & \multicolumn{6}{|c|}{ Not detectable (below the detactable level) } \\
\hline
\end{tabular}

aPTWI (Provisional Tolerable Weekly Intake) in $\mathrm{mg} / \mathrm{week} / \mathrm{kg}$ body wt.

${ }^{b}$ PTWI for $70 \mathrm{~kg}$ adult person (mg/week/70 kg body wt.)

'PTDI (Permissible Tolerable Daily Intake) (mg/day/70 kg body wt.)

${ }^{\mathrm{d}}$ EWI (Estimated Weekly Intake) (mg/week/ kg body wt.)

${ }^{\mathrm{e}} \mathrm{EDI}$ (Estimated Daily Intake) (mg/day/ kg body wt.)

\subsection{Discussions}

According to recent reviews (Bat, 2014; Bat, 2017), results usually indicated that heavy metal absorptions remained minimal in the muscular tissues and maximal in the liver and gill. It has been revealed that destination tissues of toxic metals are metabolically active ones. Consequently, metal accumulation in destination tissues follow up greater amount compared to other tissues like the muscle, where metabolic activity is relatively weak (Kalay et al., 1999; Roesijadi and Robinson, 1994; Serra et al., 1993; Langston, 1990; Heath, 1987).

Overall the toxic heavy metal such as $\mathrm{Pb}$ was not observed or below detectable level in raw and processed muscles of selected species of fish, it indicates that our traditional culinary practice did not effect on it. Musaiger and D'Souza (2008) observed that low level content of $\mathrm{Pb}$ i.e. $(\geq 0.02) \mu \mathrm{g} / \mathrm{g}$ in most of the cooked species of fish and shrimp of Arabian Gulf. In the present study the essential heavy metals such as $\mathrm{Fe}, \mathrm{Zn}, \mathrm{Cu}$ and $\mathrm{Mn}$ tend to increase in all fin 
fishes after cooking, especially in curried form. It might be the reason of this increase is the usage of vegetables, yoghurt and citrus ingredients in traditional curry preparation (Musaiger 2006). The increases of $\mathrm{Fe}, \mathrm{Zn}, \mathrm{Cu}$ and $\mathrm{Mn}$ contents in fried form of finfish is may be the adding of gram flour batter coating on fillets. Gram flour is also rich in fibres, vitamin B-6, folate, thiamine, magnesium, phosphorus, potassium, manganese, iron, zinc and copper. It was also observed (Tawfik, 2013) the increase values of heavy metals after culinary practice, and was concluded that in the frying and marinated methods, the concentrations of metals increased. According to Bassey et al., (2014), the cooking methods produced remarkable raise in the concentrations of most metals compared to those of the uncooked samples. On the other hand, these culinary practices withal caused a decline in the amounts of metals in some fish species. This ways could be recognised to the interaction among the body size of the cooked fish, water loss, oil uptake and metal evaporation in the course of processing. However, according to Mitra et al. (2011), heat treatment by frying, boiling, steaming and curry preparation of fish lead to a reduction of the heavy metal amount in the muscle of all fish species. Devi and Sarojnalini (2012) observed the same as the decrease content of heavy metals in fry and curry form of Fish Amblypharyngodon mola.

In the present study the content of toxic heavy metal $\mathrm{Hg}$ was observed in all raw samples particularly in raw Mulla fish but heat treatment by frying and curry preparation of fish led to a decrease of $\mathrm{Hg}$ content in the muscles of all selected species especially in L. nebulosus after frying. However in A. arabicus, $\mathrm{Hg}$ content was below detectable level. According to Panichev and Panicheva (2016) cooking in sunflower oil might be the further example of thermal elimination of $\mathrm{Hg}$ from the fat fishes. They found $19.1 \%$ loss of $\mathrm{Hg}$ for rich in fat Yellowtail and only $5.9 \%$ for lean Cape hake fish.

In the present study the concentration of $\mathrm{Cd}$ and $\mathrm{Cr}$ was observed at below detectable levels in all selected species except in A. arabicus where $\mathrm{Cd}$ tends to decrease after frying. The conflicting result has been observed by Bassey et al. (2014) where $\mathrm{Cd}$ tend to increase in Polydactylus quadratifilis after frying and grilling. Musaiger and D'Souza (2008) reported that the remained steady value i.e. $\geq 0.02 \mu \mathrm{g} / \mathrm{gm}$ of $(\mathrm{Cd})$ for all the methods of cooking. Decrease in the metal levels during fish processing may be associated to the discharge of these contaminants by the loss of water as free salts, maybe in relation to soluble amino acids and uncoagulated proteins (Bryan and Hummerstone 1971). In A. arabicus the content of Cr slightly increase after both types of cooking. The same observed by Tawfik (2013) in fin fish species Oreochromis niloticus, Mugil cephalus, Sardinops saga and fried shrimp Penaeus monodon which showed increase values of $\mathrm{Cr}$ after frying and marinated form. Ahmed et al. (2015) pointed out that the $\mathrm{Cr}$ is very important for human diet because of its key role in insulin function and lipid metabolism. With respect to Western Australian Food and Drug legislations, the recommended maximal permissible amount of $\mathrm{Cr}$ is $5.5 \mu \mathrm{g} / \mathrm{g}$ (Plaskett and Potter, 1979). According to Bassey et al. (2014) the increase of $\mathrm{Cr}$ in the course of frying could be due to moisture loss and uptake of $\mathrm{Cr}$ from the oil during frying.

In this study the species wise differences was not constant for all the detected heavy metals. The obtained variation of metal amounts in several species counts on feeding habits (Romeo et al., 1999) environmental requirements, metabolism (Canli and Furness, 1993), their habitats (Canli and Atli, 2003; Tuzen and Soylak, 2006) and age, size and length of the species (Linde et al., 1998). The practice of culinary therefore plays a key role in altering the absorptions of heavy metals.

The several ways of cooking have a significant effect on the nutrient and heavy metal composition of fish. The changes are subject to on culinary circumstances (time, temperature and medium of cooking). It is found that the traditionally fried $P$. argenteus and curried form of $L$. nebulosus as a routine portion of the diet 
would be useful because of its rich content of $\mathrm{Fe}$, $\mathrm{Zn}$ and $\mathrm{Cu}$. In the present study the increase in essential heavy metal contents could be due to the ingredients used in traditionally cooking practices. Consequently, it is probable to decrease the heavy metals in fish muscles by selecting an appropriate process of cooking. Atta et al. (1997) found that the $\mathrm{Cd}, \mathrm{Cu}, \mathrm{Pb}$ and $\mathrm{Zn}$ levels in Tilapia nolitica decreased on steaming and baking. However the reduction in these metal levels on baking was much higher than on steaming (Atta et al., 1997). In this study our results make public that heat energy has the significant role in separation of heavy metals from the fish. Hence in conclusion it can be encouraged that polluted fish by toxic heavy metal (such as $\mathrm{Hg}$ in L. nebulosus) may be consumed after traditionally culinary practice of the study. Thus, it is likely to reduce the metal levels in fish by choosing a proper method of cooking. Consequently, such fish flesh should only be consumed after cooking (Atta et al., 1997).

The tolerable weekly intake of the metals as PTWI (Provisional Tolerable Weekly Intake), are established by the Food and Agriculture Organization/World Health Organization (FAO/WHO) Joint Expert Committee on Food Additives (JECFA). PTWI is the maximal level of a pollutant to which a person can be exposed per week over a lifespan with no health risk effects (National Academy of Science, 1989; WHO, 1996; Council of Europe, 2001; FAO/WHO, 2010; EFSA, 2010; EFSA, 2012). EWI levels of metals for a person $(\mathrm{mg} / 70 \mathrm{~kg}$ body weight) consuming $38.36 \mathrm{~g}$ seafood/week were estimated using the mean \pm SD metal levels (see Tables 6-8) for P. argentus, $L$. nebulosus and $A$. arabicus. Intake estimates were expressed as per unit body weight $(\mathrm{mg} / \mathrm{kg}$ body wt. /weekly and daily). EDI values were calculated from EWI values.

\section{Conclusions}

In this study, the calculated EWIs and EDIs of the metals are under the permitted PTWIs and
PTDIs and showed no hazard consequences to the consumers.

\section{References}

Ahmed, M.K., Shaheen, N., Islam, M.S., Habibullah-al-Mamun, M., Islam, S., Mohiduzzaman, M., \& Bhattacharjee, L. (2015). Dietary intake of trace elements from highly consumed cultured fish (Labeo rohita, Pangasius pangasius and Oreochromis mossambicus) and human health risk implications in Bangladesh. Chemosphere, $128,284-292$.

Ahmed, Q., Bat, L., Yousuf, F., \& Arici, E. (2016). Heavy metals in Acanthopagrus arabicus Iwatsuki, 2013 from Karachi Coasts, Pakistan and potential risk of human health. International Journal of Fisheries and Aquatic Studies, 4(1), 203-208.

Ashraf, W. (2005). Accumulation of heavy metals in kidney and heart tissues of Epinephelus microdon fish from the Arabian Gulf. Environmental Monitoring and Assessment, 101, 311-316.

Atta, M.B., El-Sebaie, L.A., Noaman, M.A. \& Kassab, H.E. (1997). The effect of cooking on the content of heavy metals in fish (Tilapia nilotica). Food Chemistry, 58(1-2), 1-4.

Balkas, T.I., Tugrul, S., \& Salihoglu, I. (1982). Trace metal levels in fish and crustaceans from northeastern Mediterranean coastal waters. Marine Environmental Research, 6 (4), 281-289.

Bassey, F.I., Oguntunde, F. C., Iwegbue, C. M. A., Osabor, V. N., \& Edem, C. A. (2014). Effects of processing on the proximate and metal contents in three fish species from Nigerian coastal waters. Food Science \& Nutrition, 2(3), 272-281.

Bat, L. (2005). A review of sediment toxicity bioassays using the amphipods and polychaetes. Turkish Journal of Fisheries and Aquatic Sciences, 5, 119-139.

Bat, L. (2014). Heavy metal pollution in the Black Sea. In Düzgünes, E., Öztürk, B., \& Zengin, M. (Eds.), Turkish Fisheries in the Black Sea, Publication number: 40, Turkish 
Marine Research Foundation (TUDAV), Istanbul, Turkey, pp. 71-107.

Bat, L. (2017). The contamination status of heavy metals in fish from the Black Sea, Turkey and potential risks to human health. In Sezgin, M., Bat, L., Ürkmez, D., Arici, E., \& Öztürk, B. (Eds.), Black Sea Marine Environment: The Turkish Shelf. Turkish Marine Research Foundation (TUDAV), Publication No: 46, Istanbul, Turkey, pp. 322-418.

Bat, L., \& Raffaelli, D. (1998). Sediment toxicity testing: A bioassay approach using the amphipod Corophium volutator and the polychaete Arenicola marina. Journal of Experimental Marine Biology and Ecology, 226, 217-239.

Bat, L., Gökkurt, O., Sezgin, M., Üstün, F., \& Sahin F. (2009). Evaluation of the Black Sea land based sources of pollution the coastal region of Turkey. The Open Marine Biology Journal, 3, 112-124.

Bat, L., \& Özkan E.Y. (2015). Heavy metal levels in sediment of the Turkish Black Sea coast. In Bikarska, I., Raykov, V., \& Nikolov, N. (Eds.), Progressive Engineering Practices in Marine Resource Management. Chapter 13, IGI Global book series Advances in Environmental Engineering and Green Technologies (AEEGT) USA, pp. 399-419.

Bat, L., Özkan, E.Y., \& Öztekin, H.C. (2016). The contamination status of trace metals in Sinop coast of the Black Sea, Turkey. Caspian Journal of Environmental Sciences, 13(1), 1-10.

Bat, L., Özkan, E.Y., Büyükisik, H.B., \& Öztekin, H.C. (2017). Assessment of metal pollution in sediments along Sinop peninsula of the Black Sea. International Journal of Marine Science, 7 (22), 205-213.

Bat, L., \& Arici, E. (2018). Heavy metal levels in fish, molluscs, and crustacea from Turkish seas and potential risk of human health. Chapter 5. In Holban, A.M., \& Grumezescu, A.M. (Eds.), Handbook of Food Bioengineering, VOL. 13, Food Quality:
Balancing Health and Disease. Elsevier, Academic Press, pp. 159-196.

Bryan, G. W., \& Hummerstone, L.G. (1971). Adaptation of the polychaete Nereis diversicolor to estuarine sediments containing high concentrations of heavy metals. I. General observations and adaptation to copper. Journal of the Marine Biological Association of the United Kingdom, 51, 845-63.

Burger, J., \& Gochfeld, M. (2011). Mercury and selenium levels in 19 species of saltwater fish from New Jersey as a function of species, size and season. Science of the Total Environment, 409, 1418-1429.

Canli, M., \& Furness, R.W. (1993). Toxicity of heavy metals dissolved in seawater and influences of sex and size on metal accumulation and tissue distribution in the Norway lobster Nephrops norvegicus. Marine Environmental Research, 36, 217236.

Canli, M., \& Atli, G. 2003. The relationships between heavy metal $(\mathrm{Cd}, \mathrm{Cr}, \mathrm{Cu}, \mathrm{Fe}, \mathrm{Pb}, \mathrm{Zn})$ levels and the size of six Mediterranean fish species. Environmental Pollution, 121, 129136.

Chen, M.H., Shih, C.C., Chou, C.L., \& Chou, L.S. (2002). Mercury, organic-mercury and selenium in small cetaceans in Taiwanese waters. Marine Pollution Bulletin, 45, 237245.

Council of Europe. (2001). Council of Europe's policy statements concerning materials and articles intended to come into contact with foodstuffs. Policy Statement concerning materials and alloys. Technical Document. Guidelines on metals and alloys used as food contact materials, Strasbourg.

Devi, W. S., \& Sarojnalini Ch. (2012). Impact of different cooking methods on proximate and mineral composition of Amblypharyngodon mola of Manipur. International Journal of Advanced Biological Research, 2(4), 641645.

Diaconescu, C., Urdes, L., Diaconescu, S., \& Popa, D. (2012). Effects of cooking methods 
on the heavy metal concentrations in the fish meat originating from different areas of Danube River. Animal Science. Series D, LV, 265-267.

Diaconescu, C., Fantaneru, G., Urdes, L. Vidu, L., Vasile, B., \& Stephan, D. (2013). Influence of cooking methods over the heavy metal and lipid content of fish meat. Romanian Biotechnological Letters 18 (3), 8279-8283.

Domingo, J.L. (2011). Influence of cooking processes on the concentrations of toxic metals and various organic environmental pollutants in food: a review of the published literature. Critical Reviews in Food Science and Nutrition, 51 (1), 29-37.

EFSA Panel on Contaminants in the Food Chain. (2010). Scientific opinion on lead in food. EFSA Journal, 8 (4), 1570.

EFSA Panel on Contaminants in the Food Chain. (2012). Scientific opinion on the risk for public health related to the presence of mercury and methylmercury in food. EFSA Journal, 10 (12), 2985.

Ersoy, B., Yanar, Y., Kücükgülmez, A., \& Çelik, M. (2006). Effects of four cooking methods on the heavy metal concentrations of the sea bass fillets (Dicentrarchus labrax Linne, 1785). Food Chemistry, 99, 748-751.

FAO/WHO. (2010). Summary report of the seventy-third meeting of JECFA, Joint FAO/WHO Expert Committee on Food Additives, Geneva.

Food and Agriculture Organization of the United Nations. (2009). Fishery and aquaculture country profile. The Islamic Republic of Pakistan, FID/CP/PAK, 18 p.

Heath, A.G. (1987). Water pollution and fish physiology. CRC press, Florida, USA.

Iwegbue, C.M.A. (2011). Assessment of heavy metal speciation in soils impacted with crude oil in the Niger Delta, Nigeria. Chemical Speciation and Bioavailability, 23 (1), 7-15.

Jaffer, M., Ashraf, M., \& Tariq, J. (1995). Assessment of current trace metal pollution status of the south east Arabian Sea coast of Pakistan through fish analysis. Journal of the
Chemical Society of Pakistan, 17 (4), 204207.

Kalay, M., Ay, O., \& Canli, M. (1999). Heavy metal concentration in fish tissues from the northeast Mediterranean Sea. Bulletin of Environmental Contamination and Toxicology, 63, 671-673.

Kalay, M., Ay, O., \& Canli, M. (1999). Heavy metal concentrations in fish tissues from the Northeast Mediterranean Sea. Bulletin of Environmental Contamination and Toxicology, 63, 673-681.

Kalogeropoulos, N., Karavoltsos, S., Sakellari, A., Avramidou, S., Dassenakis, M., \& Scoullos, M. (2012). Heavy metals in raw, fried and grilled Mediterranean finfish and shellfish. Food and Chemical Toxicology, 50, 3702-3708.

Khattak, M.I., \& Khattak, M.I. (2013). Evaluation of heavy metals (As and $\mathrm{Cd}$ ) contamination in the edible fish along Karachi-Makran coast. Pakistan Journal of Zoology, 45 (1), 219-226.

Langston, W.J. (1990). Toxic effects of metals and the incidence of marine ecosystems. In: Furness RW, Rainbow PS, editors. Heavy Metals in the Marine Environment. CRC Press, New York, USA.

Linde, A.R., Sanchez-Galan, S., Izquierdo, J.I., Arribas, P., Maranon, E., \& Garcya-Vazquez, E. (1998). Brown trout as biomonitor of heavy metal pollution: effect of age on the reliability of the assessment. Ecotoxicology and Environmental Safety, 40, 120-125.

Mitra, A., Chakraborty, R., Sengupta, K., \& Banerjee, K. (2011). Effects of various cooking processes on the concentrations of heavy metals in common finfish and shrimps of the River Ganga. National Academy of Science Letters, 34 (3\&4), 161-168.

Morshey, A. El Din A.; Darwaish, W.S.; Hussein, M. A., \& El Ebidy, O.M. (2015). Heavy metals residues in marketed fish at Manzala, Dakahlyia. In: 2nd Conference of Food Safety, Suez Canal University, Faculty of Veterinary Medicine I, 112-118. 
Musaiger, A. O. (2006). Food Composition Tables for Arab Gulf Countries (Gulfoods). Arab Center for Nutrition, Manama-Bahrain.

Musaiger, A.O., \& D'Souza, R. (2008). The effects of different methods of cooking on proximate, mineral and heavy metal composition of fish and shrimps consumed in the Arabian Gulf. Archivos Latinoamericanos de Nutricion, 58, 103-109.

National Academy of Science. (1989). Recommended Dietary Allowances, 10th Edition, National Academy Press, Washington, D.C., USA.

Naughton, D.P., \& Petroczi, A. (2008). The metal ion theory of ageing: dietary target hazard quotients beyond radicals. Immune \& Ageing, 5, 3.

Panichev, N. A., \& Panicheva, S. E. (2016). Influence of different cooking procedure on the $\mathrm{Hg}$ concentration in fish. Journal of Fisheries Sciences, 10 (1), 63-69.

Plaskett, D., \& Potter, I. (1979). Heavy metal concentrations in the muscle tissue of 12 species of teleost from Cockburn Sound, Western Australia. Marine and Freshwater Research, 30, 607-616.

Renzoni, A., Zino, F., \& Franchi, E. (1998). Mercury levels along the food chain and risk for exposed populations. Environmental Research, 77, 68- 72.

Roesijadi, G., \& Robinson, W.E. (1994). Metal regulation in aquatic animals: Mechanism of uptake, accumulation and release. In Malins, D.C. \& Ostrander, G.K. (Eds.), Aquatic Toxicology (Molecular, Biochemical and Cellular Perspectives), Lewis Publishers, London, England.

Romeo, M., Siau, Y., Sidoumou, Z., \& GnassiaBarelli, M. (1999). Heavy metal distribution in different fish species from the Mauritania coast. Science of the Total Environment, 232, 169-175.

Serra, R., Carpene, E., Torresani, G., Andreucci, A., \& Grandini, S. (1993). Concentrations of $\mathrm{Zn}, \mathrm{Cu}, \mathrm{Fe}$, and $\mathrm{Cd}$ in Liza ramada and Leuciscus cephalus. Archivio Veterinario Italiano, 44, 166-174.
Stanescu, V. (1998). Food hygiene and control, Romania Tomorrow Foundation Publisher, Bucharest, 59.

Tariq, J., Ashraf, M., Jaffer, M., \& Masud, K. (1998). Selected trace metal concentration in seven fish species from the Arabian Sea, Pakistan. Journal of the Chemical Society of Pakistan, 20 (4), 249-251.

Tawfik, M.S. (2013). Impact of different cooking processes on proximate metals composition of fish and shrimp. Journal of Food Technology, 11, 95-102.

Tuzen, M., \& Soylak, M. (2006). Chromium Speciation in Environmental Samples by Solid Phase Extraction on Chromosorb 108. Journal of Hazardous Materials, 129, 266273.

WHO. (1996). Trace elements in human nutrition and health. (NLM Classification: QU 130), Geneva.

\section{Acknowledgment}

The researchers wish to acknowledge the Higher Education Commission, Government of Pakistan (Grant No. Project \# 21475/SRGP/R\&D/HEC/2 014) which supported by financially and also to acknowledge the PCSIR Laboratories of Pakistan, Karachi and Federal Urdu University of Arts, Science and Technology Gulshan.e.Iqbal Campus for providing laboratory facilities during the study. 